\title{
OBJECT DETECTOR PROTOTYPE USING ULTRASONIC SENSOR FOR INDOOR SECURITY MONITORING SYSTEM
}

\author{
Satoro Disney Karwur'), Hesky S. Kolibu ${ }^{1)}$, Verna A. Suoth ${ }^{1)}$ \\ ${ }^{1)}$ Physics Department, University of Sam Ratulangi, \\ e-mail: satorodisneykarwur@gmail.com; heskystevy@yahoo.com; vernasuoth@yahoo.co.id
}

\begin{abstract}
A research has been conducted to make an object detector prototype using ultrasonic sensor for indoor security monitoring system. The testing object placed in front of the sensor and the measurement conducted in distance and angle variations. For indoor implementation, graphical display of object detection on computer screen given by blue-to-yellow transition to indicate the nearing object and its reverse to indicate the fading object.

The trend of accuracy of the object distance measurement has a declining linear pattern, it means that the accuracy of object detection will decrease if the distance and or angle from the object to the detector are increase.
\end{abstract}

Keywords: object detector, ultrasonic sensor, indoor security monitoring

\section{PURWARUPA DETEKTOR OBJEK MENGGUNAKAN SENSOR ULTRASONIK UNTUK SISTEM PEMANTAUAN KEAMANAN DALAM RUANGAN}

\begin{abstract}
ABSTRAK
Sebuah penelitian telah dilakukan untuk membuat purwarupa detektor objek menggunakan sensor ultrasonik untuk sistem pemantauan keamanan dalam ruangan. Objek pengujian diletakkan di depan sensor dan pengukuran dilakukan pada variasi jarak dan sudut. Untuk implementasi dalam ruangan, tampilan grafis pendeteksian objek pada layar komputer diberikan oleh transisi warna biru ke kuning untuk menunjukkan objek yang mendekat dan kebalikannya untuk menunjukkan objek yang menjauh.

Tren akurasi pendeteksian objek memiliki pola menurun secara linear, itu berarti bahwa akurasi pendeteksian objek akan berkurang jika jarak dan atau sudut dari objek ke detektor bertambah besar.
\end{abstract}

Kata kunci: detektor objek, sensor ultrasonik, pemantauan keamanan dalam ruangan

\section{INTRODUCTION}

Security protection for assets or individuals conducted from household to corporate scale. This has triggered the escalation of demands for variety of techniques to provide security. When assets or individuals are in a certain room, then surely its safety should be prioritized. Form of indoor security monitoring should be run as effectively as possible in order to prevent unwanted things related to assets or individuals who are in it. It encourages the creation of a variety of advanced equipment in the present day to monitor the indoor security. Indoor security monitoring needs at least a facility or an instrument to provide information or a sign of whether an asset or individual in it is really in safe condition or is undergoing a security risk such as the presence of persons who allegedly about to commit assets burglary, in attempt for kidnapping, or other suspicious and dangerous actions.

The ultrasonic sensor is one type of sensor that has been used widely to detect objects at a certain distance. Its application is often encountered in everyday life, both for practical and scientific purposes. Gageik et al. (2012) created collision avoidance instrument for unmanned aerial vehicles using ultrasonic sensors as its main 
component and has also developed an unmanned aerial vehicle that can detect an object from different directions (Niuwenhuisen et al., 2013). Object detection using ultrasonic sensor for indoor usage has some advantages than for outdoor usage. For outdoors applications, they poses environmental factors such as temperature that radically changes, air pressure and wind direction and velocity that fluctuates overtime, and other atmospheric influences, while at indoor scale, all of these factors have no significant effects (Mubarak, 2013). Because the ultrasonic sensor works on high frequency range above the limit of human hearing ability, so it is also appropriate for monitoring in silent situation (Morris, 2001). These facts indicates that the object detection using ultrasonic sensor could be used to answer the challenges related to the security monitoring that are explained above.

The problem is of this research is how to make an object detector using ultrasonic sensor and how to implement the object detector for indoor security monitoring. This research is limited under the following conditions: the sensor only implemented for indoor security monitoring, s a prototype, the product of this research can only be running on specific serial communication on specific computer, in this research, air temperature and pressure factors are ignored, the sensor only used to detect the object in monitoring area.

This research aims to make a prototype of object detector using ultrasonic sensor and to implement the prototype for indoor security monitoring. Besides, this research also has an objective to give information about the influence of the distance and angle variation to the detection accuracy of the sensor.

\section{LITERATURE REVIEW}

\section{Measurement and Instrumentation}

Measurement is an activity that always needed in daily life. In facts, human tends to measure everything which interact with them. In physics, it has a huge and important role to open our understanding of certain physical phenomenon. Placko (2007) stated that all existing tools that help us carry out measurement are part of instrumentation. A measuring system exists to provide information about the physical value of some variable being measured.

A sensor is an element in measurement system that detects the magnitude of a physical parameter and changes it into a signal that can be processed by the system. The term sensor is often used to refer to the transducer or to the combination of transducer and signal processor (Alciatore and Histand, 2012).

\section{Sound Waves}

Sound waves fall into three categories covering different ranges of frequencies. Infrasonic waves are longitudinal waves with frequencies below the audible range. Earthquake waves are an example. Ultrasonic waves are longitudinal waves with frequencies above the audible range for humans (Serway, 2009).

Compressional waves are mechanical waves that propagate through the interior of the material as pressure fluctuations. A characteristic of longitudinal waves is that the motion of the particles goes back and forth along the same direction in which the wave travels.

\section{Ultrasonic Sensor}

The object distance is proportional to the echo travel time (to and from the object) as the velocity of sound $v$ is known to be 344 meters per second in the air at standard temperature and pressure. The range $d$ to the object or target is calculated by the following equation:

$$
d=\frac{v t}{2}
$$

The distance $d$ is equal to multiplication of speed of sound $c$ and time taken $t$ by the pulse to and from the object. The division with " 2 " converts the total distance traveled by the pulse to half the distance, which is the distance to the object (Mubarak, 2013).

Ultrasonic sensor provides an easy method of distance measurement. This sensor is perfect for any number of applications that requires to perform measurements between moving or stationary objects.

\section{Arduino Uno R3}

One of the most reliable version of Arduino is the Arduino Uno. It is a microcontroller board based on the 
ATmega328P. It has 14 digital input/output pins, 6 analog inputs, a $16 \mathrm{MHz}$ ceramic resonator, a USB connection, a power jack, an ICSP header, and a reset button. It contains everything needed to support the microcontroller; simply connect it to a computer with a USB cable or power it with a AC-to-DC adapter or battery to get started.

The Arduino Uno can be powered via the USB connection or with an external power supply. The board can operate on an external supply of 6 to 20 volts. The recommended range is 7 to 12 volts.

\begin{tabular}{|c|c|c|c|}
\hline Arduino function & & & Arduino function \\
\hline eset & NT14/RESET) PC & LLPCINT1 & analog input 5 \\
\hline digital pin $0(\mathrm{BX})$ & (PCINT16/RXD) PDoC ${ }_{2}$ & 27. PPC4 (ADC4/SDA/PCINT12 & analog input 4 \\
\hline digital pin $1(T X)$ & (PCINT17/XX) PD1 ${ }_{3}$ & 26 PC3 (ADC3/PCINT11) & analog input 3 \\
\hline digital pin 2 & (PCINT18/NTO) PD2Д & ${ }_{25} \mathrm{PPC2}$ (ADC2/PCINT 10) & analog input 2 \\
\hline digital pin 3 (PWM) & (PCINT19/OC2B/NT1) PD3 & $24 \mathrm{PPC1}$ (ADC1 1 PCINT9) & analog input 1 \\
\hline digital pin 4 & (PCINT20/XCKTTO) PD4 & $23[\mathrm{PCO}$ (ADCO/PCINT8) & analog input 0 \\
\hline $\mathrm{VCC}$ & $\operatorname{vcc} 7$ & 2 PGND & GND \\
\hline GND & GNDC: & ${ }_{21}$ AREF & analog reference \\
\hline crystal & (PCINT6/XTAL1/TOSC1) PB6C & 20 D Avcc & vcc \\
\hline crystal & (PCINT7/XTAL2TOSC2) PB7 10 & 19.7 PB5 (SCK/PCINT5) & digital pin 13 \\
\hline digital pin $5(\mathrm{PWM})$ & (PCINT21/OCOB/T1) PD5D" & 18 PB4 (MISO/PCINT4) & digital pin 12 \\
\hline digital pin 6 (PWM) & (PCINT22/OCOA/AINO) PD6 & 17. $\mathrm{PB} 3$ (MOSI/OC2A/PCINT3) & 3) digital pin 11(PWM) \\
\hline digital pin 7 & (PCINT23/AIN1) PD7 & $16[\mathrm{~PB} 2$ (SS/OC1B/PCINT2) & digital pin 10 (PWM) \\
\hline digital pin 8 & (PCINTO/CLKO/CP1) PBOC 14 & 15 15 PB1 (OC1APCINT1) & digital pin 9 (PWM) \\
\hline
\end{tabular}

Figure 1. ATmega328P to Arduino Pin Mapping.

\section{Indoor Security Monitoring System}

Indoor security monitoring is a human activity which is very important to observe and to control the security of facilities, properties, or individuals in closed space or room. Assessing and defining vulnerable spots or area for indoor security monitoring also important to anticipate the security risks. (Petruzzellis, 1994).

The choice of sensors will depend on such factors as the level of security protection required, the budget for system installation, the limitations on the effectiveness of certain sensors in specific locations, and barriers and obstacles within rooms or outside areas being monitored (Sclater and Traister, 2003).

\section{RESEARCH METHODOLOGY}

\section{Instrument Design}

The instrument design initiated by connecting the ultrasonic sensor to pins on the Arduino board. Then, the Arduino connected to the computer through USB connector. After that, the programming sketch uploaded both on to the Arduino board and the computer screen, respectively with Arduino IDE and Processing PDE.

\section{Sensor Specification}

HC-SR04 ultrasonic sensor pins symbol and function described in following table:

\begin{tabular}{|c|c|}
\hline Pin Symbol & Function \\
\hline VCC & 5 Volt power supply \\
\hline TRIG & Transmitter pin \\
\hline ECHO & Receiver pin \\
\hline GND & Power ground \\
\hline
\end{tabular}

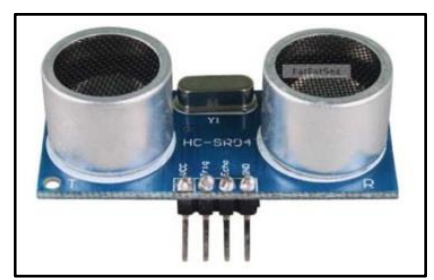

Figure 2. HC-SR04 ultrasonic sensor.

\section{Pin Connections}

The four pins of the sensor are connected to the Arduino by using jump wire through the project board as shows in the following table:

\begin{tabular}{|c|c|}
\hline $\begin{array}{c}\text { HC-SR04 } \\
\text { Pins }\end{array}$ & Arduino Uno R3 Pins \\
\hline VCC & 5 Volt pin \\
\hline TRIG & Digital pin number 2 \\
\hline ECHO & Digital pin number 3 \\
\hline GND & Gnd pin \\
\hline
\end{tabular}

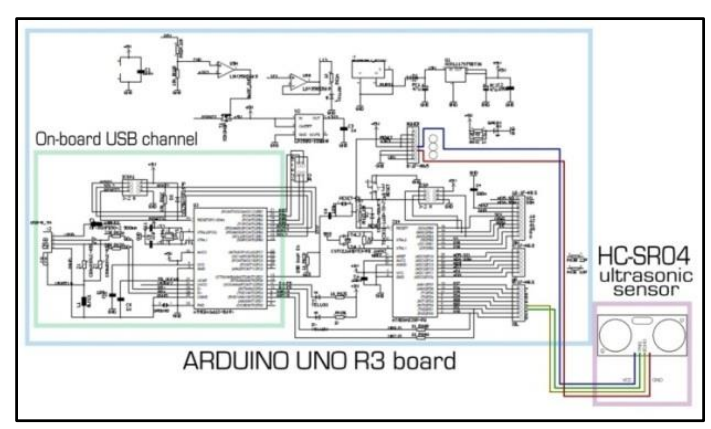

Figure 3. Instrument schematic.

\section{Instrument Testing}

Instrument testing to get the object distance data conducted by placing the sensor on top of the table with $75 \mathrm{~cm}$ high. Furthermore, the testing object in the form of a wooden block (with a height of $190 \mathrm{~cm}$ and a width of $9 \mathrm{~cm}$ ), placed in front of the sensor at a distance of $50 \mathrm{~cm}$ (using a measuring tape) and angle of 0 degrees. After collecting the object distance data of these conditions, the same procedure is then performed for the distance variations of $100 \mathrm{~cm}, 150 \mathrm{~cm}, 200$ 
$\mathrm{cm}, 250 \mathrm{~cm}, 300 \mathrm{~cm}$, and $350 \mathrm{~cm}$ as well as variations in the angle of 15 degrees, 30 degrees, 45 degrees, 60 degrees, 75 degrees, and 90 degrees. Each variation of the distance measurement is taken 20 times. Then, the distance data which collected from the Arduino IDE serial monitor compared with the distance which has measured manually using a measuring tape.

Followed by program sketching on the Processing PDE software, the object detection monitored by running the program sketch for on-screen display.

\section{RESULTS AND DISCUSSION}

\section{Instrument Testing Results}

Data which collected from the serial monitor shows that the instrument accuracy decrease as the escalation of distance and angle. At the measured distance of $50 \mathrm{~cm}$ and angle of 0 degree, the accuracy is $99,54 \%$. The difference on accuracy between the nearest position $(50 \mathrm{~cm})$ and the longest position $(350 \mathrm{~cm})$ of the object is just about $0,38 \%$.

For obejct distance measurement at the angle of 15 degree from the sensor, accuracy fall from $98,88 \%$ at the nearest position to $96,80 \%$ the longest position $(2,08$ $\%$ difference).

At the angle variation of 30 degree, the object distance measurement accuracy decreased drastically from $98,22 \%$ at the first position $(50 \mathrm{~cm})$ to $92,06 \%$ at the third position $(150 \mathrm{~cm})$. Beyond these distance variations, the instrument seems unable to get information about the distance of the object from the sensor.

According to the results of instrument testing that shows its change in accuracy through different treatment (on angle and distance variations), this means that the accuracy of object detection will decrease if the distance and or angle from the object to the detector are increase.

If the object detector placed or mounted at the height of $75 \mathrm{~cm}$ from the ground surface at any indoor location, its perimeter should be defined as long as 350 $\mathrm{cm}$ from the sensor and as width as $251 \mathrm{~cm}$.

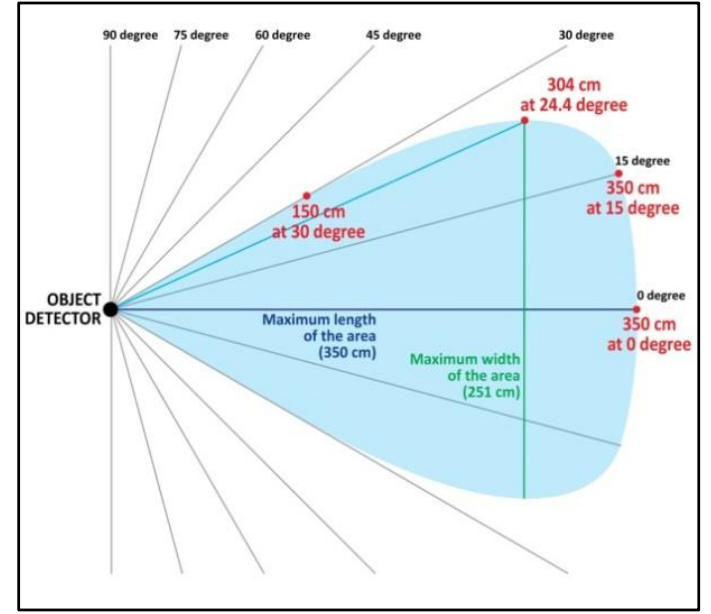

Figure 4. The most effective area for monitoring.

\section{On-screen Display}

Data processing for on-screen display simplified to show at least two graphical information: the information that could indicates that there is a nearing object or person and in turn, the information that could indicates there is a fading object or person in the monitoring area. These information given by color transition on the computer screen overtime. When an object comes near or towards to the object detector, the graphical display shows blue-to-yellow transition and yellow-to-blue transition when an object fades.

The right corridor on the first floor at Administration Builiding of FMIPA Unsrat has been chosen to implement the instrument prototype This section is considerably vulnerable for criminal actions because its strategic position in the Administration Building of FMIPA Unsrat, especially at night. The object detector mounted on a table with height of $75 \mathrm{~cm}$ from the floor and a distance of $319 \mathrm{~cm}$ from the metal fence in front of it which has defined as the security perimeter. Each pixel on monitoring screen's height represents $0,415 \mathrm{~cm}$ on the real distance, which obtained by dividing the screen's height (768 pixels) with the length of the security perimeter $(319 \mathrm{~cm})$.

Image of the object detection on computer screen displayed at $1200 \times 768$ pixel window with dark blue background. Object distance indicator determined by the change of shape's position to the window's height. 


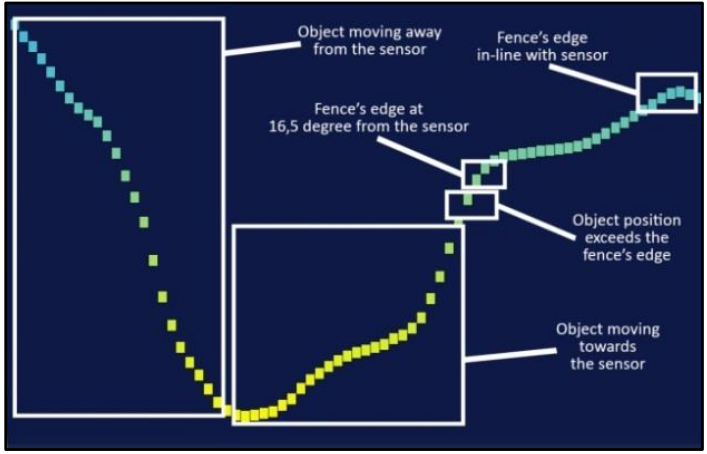

Figure 5. Image of object detection on computer screen.

Shape's height shows that in situation where there is no fence or other object movement in the security monitoring area, then the shape's height is on 0 pixel, 767 pixel, or 768 pixel, while if there is a movement of the fence or other object in monitoring area, then the shape's height will be on 1 to 766 pixel. Because of the shape's height on 0 pixel and 767 to 768 pixel represents the normal position of the fence, then the condition stated as secure condition. Shape's height on 470 to 766 pixel represents the movement of the fence's edge from its normal position to maximum opening which categorized as insecure condition. The security condition will be stated as in danger if the shape's height is less than 470 pixel, because it is indubitable that there are other objects in the monitoring area in addition to the iron fence

The following table shows the security condition category based on shape's height on the computer's screen

\begin{tabular}{|c|c|}
\hline $\begin{array}{c}\text { On-screen } \\
\text { Shape's Height } \\
\text { (pixel) }\end{array}$ & $\begin{array}{c}\text { Security } \\
\text { Condition }\end{array}$ \\
\hline 0 and 767 or768 & Secure \\
\hline $470-766$ & Insecure \\
\hline$\leq 469$ & Danger \\
\hline
\end{tabular}

An on-board LED indicator also used to indicate the security conditions. The setup simplified to inform two conditions, where the LED will turn on when there are object entering the parameter and will turn off when there is no object inside the security perimeter. This indicator can be changed with other output depends on its specific implementation. Operation of this instrument in silent state (no sound) allows the security action to person who want to do intrusion or burglary to be more effective because the monitoring process which is underway can not be immediately known or realized by the person.

\section{CONCLUSIONS AND RECOMMENDATIONS}

\section{Conclusions}

By looking this research comprehensively, some points can be stated as conclusions:

1. The trend of accuracy of the object distance measurement has a declining linear pattern, it means that the accuracy of object detection will decrease if the distance and or angle from the object to the detector are increase.

2. As a prototype, object detector using ultrasonic sensor has been proved as one of the good option to implement on indoor security monitoring system.

\section{Recommendations}

1. Future research are highly recommended due to the need for advance study about this topic.

2. For the ultrasonic sensor modification on similar research, it will be good to use more than one sensor to cover wider range of monitoring angle and also for different height.

3. This prototype also need to be improved for any kind of output indicator other than the on-screen display, such as text message or ringtone.

\section{REFERENCES}

Alciatore, D.G., and M.B. Histand. 2012. Introduction to Mechatronics and Measurement Systems. $4^{\text {th }}$ edition. McGraw-Hill, New York.

Arduino LLC, 2014. Atmega 168/328 to Arduino Pin Mapping. http://arduino.cc/en/ Hacking/PinMapping168 [April $2^{\text {nd }}$ 2014].

Atmel Corporation. 2009. ATmega328 Datasheet.

Elec-Freaks. 2011. Ultrasonic Ranging Module HC-SR04. 
Elec-Freaks. 2013. HC-SR04 User's Guide.

Gageik, N., T. Muller., and S. Montenegro. 2012. Obstacle Detection and Collision Avoidance Using Ultrasonic Distance Sensors for an Autonomous Quadrocopter. In the Proceedings of Aerospace Information Technology; Wurzburg, September 2012. University of Wurzburg.

Morris, A.S. 2001. Measurement and Instrumentation Principles. $3^{\text {rd }}$ edition. Butterworth-Heinemann, Oxford.

Mubarak, M.N. 2013. Outdoor Obstacle Detection Using Ultrasonic Sensors for an Autonomous Vehicle Ensuring Safe Operations [Thesis]. Tampere University of Technology.

Nieuwenhuisen, M., D. Droeschel., D. Holz., and S. Behnke. 2013. Omnidirectional Obstacle Perception and Collision Avoidance for Micro Aerial Vehicles. Resource-Efficient Integration of Perception, Control and Navigation for Micro Air Vehicles. In the Proceedings of RSS Workshop.

Petruzzellis, T. 1994. The Alarm, Sensor, and Security Circuit Cookbook. TAB Books, New York.

Placko, D. 2007. Fundamentals of Instrumentation and Measurement. ISTE, Newport Beach.

Sclater, N., and J.E. Traister. 2003. Handbook of Electrical Design Details. $2^{\text {nd }}$ edition. McGraw-Hill, New York.

Serway, R.A. 2009. College Physics. $8^{\text {th }}$ edition. Brooks/Cole, Belmont. 